\title{
Dampak Kebakaran Hutan Terhadap Sifat Fisik dan Kimia Tanah di Taman Nasional Kutai, Kalimantan Timur
}

\author{
Veronika Murtinah ${ }^{1}$, Muli Edwin ${ }^{2}$, Oktavina Bane ${ }^{2}$ \\ 1,2Program Studi Kehutanan, Sekolah Tinggi Pertanian Kutai Timur \\ Jl. Soekarno Hatta, No. 01, Sangatta, Kutai Timur, Kalimantan Timur, Kode Pos 75387 \\ 1email: veronikamurtinah@gmail.com
}

\begin{abstract}
Forest fires affect the physical, soil chemistry, soil biology, erosion, groundwater storing capacity, litter and humus removal. The purpose of this study was to determine the impact of forest fires on physical and chemical properties in Prevab, Kutai National Park. The research objectives were approached by comparing burnt and unburned areas. Soil samples test were conducted in the laboratory, then data analysis were performed according to the assessment of soil physical and chemical properties criterias. Based on this research, it was found that 19 years after burning, it was known that forest fires had an impact on soil physical properties, that was increasing of bulk density, decreasing porosity and soil permeability and soil texture with more dominant of sand fraction. Soil chemistry had the same criteria between burnt and unburnt areas, that were very acidic $\mathrm{pH}$, very low $\mathrm{DHL}$ and low CEC, whereas for alkaline cations were generally higher in unburnt areas than in burnt areas, except for Potassium (K).
\end{abstract}

Keywords: forest fire, chemical properties, Kutai National Park, physical properties, soil.

\begin{abstract}
ABSTRAK
Kebakaran hutan berdampak terhadap sifat fisika, kimia tanah, biologi tanah, erosi, kapasitas menyimpan air tanah, penghilangan serasah serta humus. Tujuan penelitian ini adalah untuk mengetahui dampak kebakaran hutan terhadap sifat fisik dan sifat kimia di Prevab, Taman Nasional Kutai. Tujuan penelitian didekati dengan membandingkan areal bekas terbakar dan areal tidak terbakar. Pengujian sampel tanah dilakukan di laboratorium, selanjutnya dilakukan analisis data dengan mengacu pada kriteria penilaian sifat fisik dan kimia tanah yang telah ditetapkan. Berdasarkan penelitian ini diperoleh hasil bahwa sampai 19 tahun setelah terbakar, diketahui kebakaran hutan berdampak terhadap sifat fisik tanah, yaitu meningkatnya kerapatan lindak/Bulk Density, penurunan porositas dan permeabilitas tanah serta tekstur tanah dengan fraksi pasir lebih dominan. Sifat kimia tanah memiliki kriteria yang sama antara areal bekas terbakar dan tidak terbakar yaitu $\mathrm{pH}$ sangat masam, DHL sangat rendah dan KTK rendah, sedangkan untuk kation-kation basa secara umum lebih tinggi pada areal tidak terbakar dibandingkan dengan areal terbakar, kecuali untuk Kalium (K).
\end{abstract}

Kata kunci: kebakaran hutan, tanah, sifat fisik, sifat kimia, Taman Nasional Kutai

\section{Pendahuluan}

Kebakaran hutan adalah suatu keadaan saat hutan dilanda api sehingga mengakibatkan kerusakan hutan dan/atau hasil hutan yang menimbulkan kerugian ekonomis dan/atau nilai lingkungan (Kep.Menhut No.195/Kpts-II/1986). Kebakaran hutan dan lahan di Indonesia merupakan fenomena yang sering terjadi terutama dimusim kemarau (Hidayat, 2006).

Faktor penyebab terjadinya kebakaran hutan dan lahan, yaitu oleh faktor alam, antara lain musim kemarau, iklim yang ekstrem, adanya deposit batu bara maupun oleh faktor manusia yang disengaja, misalnya dalam penyiapan lahan tanam dan tidak 
disengaja. Menurut Prakoso (2004) lebih dari 90\% kebakaran hutan disebabkan oleh faktor manusia.

Kebakaran hutan menimbulkan banyak dampak merugikan baik dari segi ekologi hingga ekonomi (WWF, 2015). Kebakaran merupakan penyebab kerusakan hutan yang paling besar, yang mana dalam waktu singkat dapat menghancurkan kawasan yang cukup luas. Kebakaran hutan ternyata lebih banyak menimbulkan dampak negatif daripada dampak positif terhadap sifat-sifat tanah dan terutama terhadap erosi. (Hatta, 2009).

Kebakaran hutan mengakibatkan kerusakan ekologis, menurunkan nilai estetika, merosotnya nilai ekonomi kehutanan dan produktivitas tanah, perubahan iklim mikro maupun global, menurunnya keanekaragaman hayati dan ekosistem. Kebakaran hutan juga menyebabkan dampak negatif terhadap tanah berupa penurunan kualitas tanah, meliputi sifat fisika tanah, kimia tanah, biologi tanah, erosi, kapasitas menyimpan air tanah, penghilangan serasah serta humus, seluruhnya akan berpengaruh terhadap pertumbuhan pohon selanjutnya di areal tersebut. Dampak kebakaran hutan terhadap sifat fisika dan kimia tanah tergantung dari tipe tanah, kandungan air tanah, intensitas, durasi waktu kebakaran, lama waktu dan intensitas timbulnya api (Chandler et al., 1983).

Dampak kebakaran terhadap sifat fisik tanah terutama disebabkan oleh terbukanya tajuk, humus dan serasah ikut terbakar, struktur tanah memburuk dan akhirnya rentan terhadap erosi. Pengaruh kebakaran terhadap sifat fisik tanah akan jelas tampak pada perubahan tekstur tanah, kerapatan lindak (bulk density), porositas dan permeabilitas. Beberapa penelitian terkait dengan hal tersebut telah dilakukan, antara lain oleh Yudhasworo (2001) dan Prakoso (2004) pada areal hutan sekunder, Wasis (2003) pada areal hutan di Kalimantan Tengah, Sagala (2006) pada areal hutan di Kabupaten Samosir dan Hidayat (2006) pada areal padang rumput.

Pada sifat kimia tanah kebakaran hutan memberikan masukan mineral yang terdapat di dalam abu atau arang sehingga dapat menaikkan $\mathrm{pH}$ tanah dan menambah nilai hara tanah, tetapi pengaruh ini tidak berlangsung lama karena dengan terbukanya tajuk, pencucian menjadi lebih intensif (Hidayat, 2006)

Obyek penelitian memungkinkan untuk meneliti perubahan-perubahan atau perkembangan sifat fisik dan kimia tanah secara alami (dalam hutan lindung) yaitu pada areal bekas terbakar (19 tahun) dan membandingkannya dengan areal tidak terbakar. Tujuan dari penelitian ini adalah untuk mengetahui dampak kebakaran hutan terhadap sifat fisik dan sifat kimia di Prevab, Taman Nasional Kutai. 


\section{Metode Penelitian}

\subsection{Waktu dan Lokasi}

Penelitian dilaksanakan selama 5 bulan, selama Desember 2016 hingga April 2017. Pengambilan sampel tanah dilakukan pada areal bekas terbakar (19 tahun) dan tidak terbakar di kawasan hutan alami Prevab, Taman Nasional Kutai. Uji laboratorium sifat fisik dan kimia tanah dilaksanakan di Laboratorium Tanah Fakultas Pertanian Universitas Mulawarman, Samarinda.

\subsection{Alat dan Bahan}

Peralatan yang digunakan dalam penelitian ini adalah:

a) GPS (Global Positioning System) untuk mengetahui posisi koordinat geografik titik pengamatan di lokasi penelitian.

b) Kompas untuk menentukan arah penampang terhadap lereng atau letak penampang terhadap sesuatu tanda tetap di lapangan.

c) Cangkul untuk menggali lubang penampang/profil tanah.

d) Meteran untuk mengukur kedalaman penampang/tanah, ketebalan dan batas lapisan (horizon).

e) Garpu tanah atau cutter untuk menarik garis atau menandai batas lapisan, perbedaan warna tanah, mengambil contoh tanah terusik.

f) Ring sampel (tabung sampel) tanah untuk mangambil contoh tanah utuh.

g) Plastik sampel tanah untuk menyimpan sampel tanah komposit.

h) Spidol permanen untuk menulis label pada sampel tanah.

i) Kamera sebagai alat dokumentasi di lapangan

j) Komputer untuk pengolahan data

Bahan yang digunakan dalam penelitian ini adalah sampel tanah yang akan dianalisis di laboratorium tanah, peta tanah dan peta lainnya untuk mendukung penelitian.

\subsection{Prosedur Penelitian}

Lokasi penelitian ditentukan secara sengaja (purposive sampling) pada lokasi yang representatif dan belum terganggu di areal bekas terbakar dan tidak terbakar di areal hutan alami Prevab, Taman Nasional Kutai. Prinsip dalam penetapan lokasi pengambilan sampel berdasarkan kondisi topografi atau kelerengan di kedua lokasi tersebut. Pada setiap lokasi ditentukan dua titik pengambilan sampel, yaitu pada punggung bukit dengan kemiringan lahan 8-15\% dan pada lereng bukit dengan kemiringan lahan $15-25 \%$.

Untuk keperluan pengamatan perkembangan tanah dan pengambilan sampel tanah dibuat 1 profil tanah di masing-masing lokasi penelitian. Sifat fisik tanah yang diteliti meliputi kerapatan lindak (bulk density), porositas dan permeabilitas, sampel tanah diambil dengan menggunakan ring sampel (sampel tanah utuh) yang dilakukan dengan 
cara mengambil 1 sampel tanah utuh di profil tanah masing-masing dari kelas kedalaman 0-5 cm, 5-10 cm, $10-20 \mathrm{~cm}, 20-30 \mathrm{~cm}$. Untuk pengujian tekstur tanah, sampel tanah diambil dari kelas kedalaman yang sama dengan sampel tanah utuh.

Sifat kimia tanah diuji dengan terlebih dahulu mengambil sampel tanah secara komposit dari 5 titik pengambilan sampel yang terdiri dari 1 titik pada profil tanah dan 4 titik lainnya diambil dengan radius sekitar $20 \mathrm{~m}$ dari profil tanah. Tanah yang diambil dari kelima titik tersebut dicampur lalu diambil $\pm 1 \mathrm{~kg}$ dan dimasukkan ke dalam plastik sampel tanah, ditulis kode lapangan dengan menggunakan spidol permanen untuk selanjutnya dibawa ke laboratorium.

Parameter yang diuji dalam penelitian ini meliputi beberapa sifat fisik dan sifat kimia tanah. Sifat fisik tanah terdiri dari kerapatan lindak (bulk density), porositas, permeabilitas dan kandungan fraksi tanah (tekstur tanah). Parameter sifat kimia tanah terdiri dari pH tanah, Daya Hantar Listrik (DHL), Kapasitas Tukar Kation (KTK), dan Kation basa ( $\mathrm{Ca}, \mathrm{Mg}, \mathrm{K}, \mathrm{Na})$.

Metode analisis yang digunakan untuk sifat fisik tanah yaitu tekstur tanah, dianalisis di laboratorium menggunakan metode Hydrometer after Bouyocos (pemipetan dan penimbangan fraksi tanah dalam larutan Calgon), sedangkan untuk kerapatan lindak (bulk density) pengukurannya dilakukan dengan cara pengeringan dalam oven dengan suhu $105^{\circ} \mathrm{C}$ dan penimbangan (Ruhiyat, 1997).

\begin{tabular}{|c|c|c|c|c|c|}
\hline Sifat Tanah & $\begin{array}{l}\text { Sangat } \\
\text { Rendah }\end{array}$ & Rendah & Sedang & Tinggi & $\begin{array}{c}\text { Sangat } \\
\text { Tinggi }\end{array}$ \\
\hline C (\%) & $<1,0$ & $1,0-2,0$ & $2,01-3,00$ & $3,01-5,00$ & $>5,00$ \\
\hline $\mathrm{K}(\mathrm{ma} / 100 \mathrm{~g})$ & $<0,1$ & $0,1-0,2$ & $0,3-0,5$ & $0,6-1,0$ & $>1,0$ \\
\hline $\mathrm{Na}(\mathrm{ma} / 100 \mathrm{~g})$ & $<0,1$ & $0,1-0,3$ & $0,4-,-0,7$ & $0,8-1,0$ & $>1,0$ \\
\hline $\mathrm{Mg}(\mathrm{ma} / \mathbf{1 0 0} \mathrm{g})$ & $<0,1$ & $0,4-1,0$ & $1,1-2,0$ & $2,8-8,0$ & $>8,0$ \\
\hline $\mathrm{Ca}(\mathrm{ma} / 100 \mathrm{~g})$ & $<2,0$ & $2,0-5,0$ & $6,0-10$ & $11-20$ & $>20$ \\
\hline KTK (ma/100 g) & $<5$ & $17-24$ & $17-24$ & $25-40$ & $>40$ \\
\hline Kejenuhan basa (\%) & $<20$ & $20-30$ & $36-50$ & $51-70$ & $>70$ \\
\hline Kejenuhan Al (\%) & $<10$ & $10-20$ & $21-30$ & $31-60$ & $>60$ \\
\hline $\begin{array}{l}\text { Sangat } \\
\text { Masam }\end{array}$ & Masam & $\begin{array}{c}\text { Agak } \\
\text { masam }\end{array}$ & Netral & $\begin{array}{l}\text { Agak } \\
\text { alkalin }\end{array}$ & Alkalin \\
\hline $\mathrm{pH}\left(\mathrm{H}_{2} \mathrm{O}\right)$ & $4,5-5,5$ & $5,5-6,5$ & $6,5-7,5$ & $7,5-8,5$ & $>\quad 8,5$ \\
\hline
\end{tabular}

Sumber: Anonim (2012)

Parameter sifat kimia tanah diuji di laboratorium dengan menggunakan metode sebagai berikut:

a) $\mathrm{pH}$ : Ekstraksi $\mathrm{H}_{2} \mathrm{O}$ (tanah : larutan = 1 : 2,5), pengukuran dengan $\mathrm{pH}$-meter.

b) Kation: $\mathrm{K}, \mathrm{Na}, \mathrm{Ca}, \mathrm{Mg}$, Penetapan KTK dan KB: penjenuhan dengan ammonium acetat $1 \mathrm{~N}, \mathrm{pH}=7,0$ dilanjutkan pengukuran dengan menggunakan Atomic Absorption Spectrophoto-meter (AAS). 
c) Daya Hantar Listrik (DHL): menggunakan larutan $\mathrm{NaCl} 0,01 \mathrm{M}$, pengukuran dengan menggunakan elektrode platina.

\subsection{Analisis Data}

Untuk kriteria penilaian sifat kimia tanah dengan menggunakan panduan seperti Tabel 1.

\section{Hasil dan Pembahasan}

\subsection{Gambaran Umum Lokasi Penelitian}

Kawasan Prevab Taman Nasional Kutai (TNK) secara administratif pemerintahan berada di Dusun Kabo Jaya, Kecamatan Sangatta Utara, Kabupaten Kutai Timur. Propinsi Kalimantan Timur. Secara geografis kawasan ini berada antara $0^{\circ} 31^{\prime} 55,74$ " LU dan $117^{\circ} 27^{\prime} 53,10^{\prime \prime}$ BT.

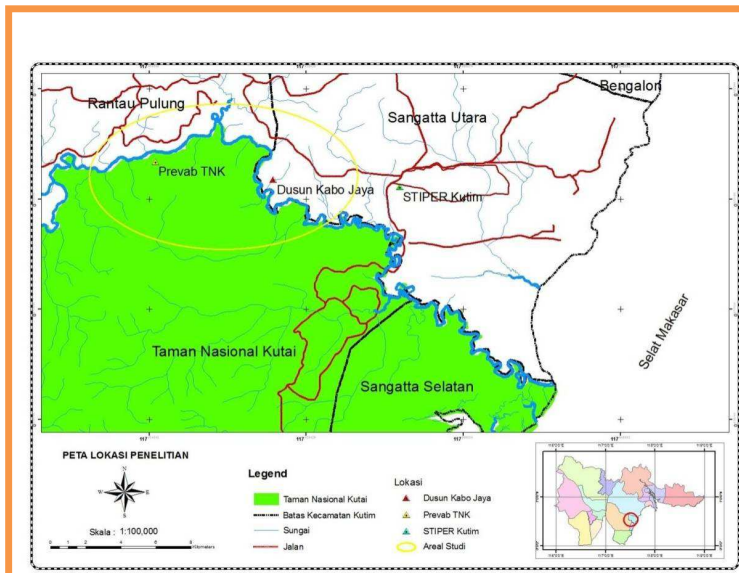

(A)

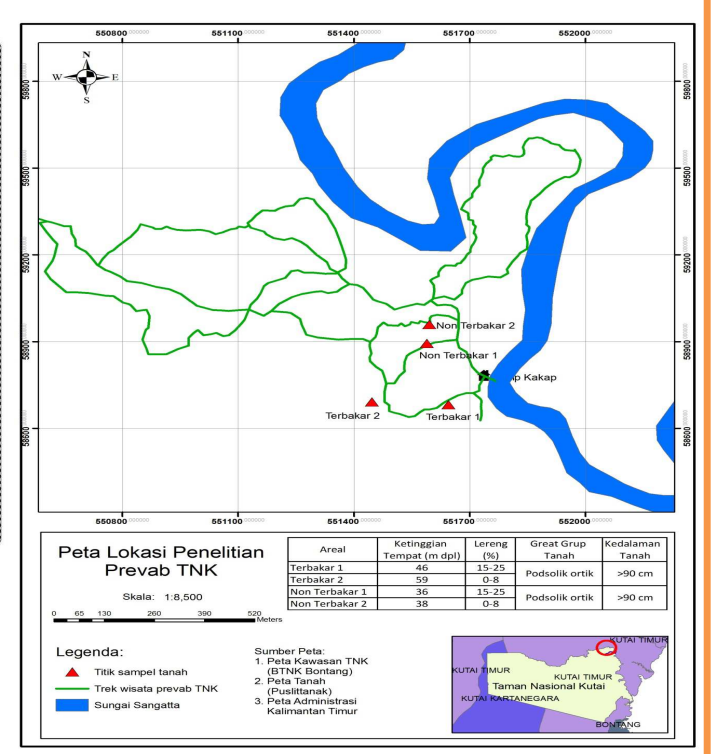

(B)

Gambar 1. (A) Kawasan Prevab, TNK (Sumber: Ramadhan, 2011); (B) Lokasi Penelitian.

Berdasarkan klasifikasi iklim Schmidt dan Ferguson, kawasan Prevab TNK termasuk tipe iklim A dengan jumlah curah hujan rata-rata tahunan sebesar $2.558 \mathrm{~mm}$ (berkisar antara 1.549-2.993 mm), curah hujan rata-rata bulanan sebesar 188,2 mm. Suhu udara rata-rata adalah $26^{\circ} \mathrm{C}$ (berkisar antara $21-34^{\circ} \mathrm{C}$ ) dan kelembapan udara berkisar antara 67-90\%, kecepatan angin normal rata-rata 2-4 knot/jam (Ramadhan, 2011).

\subsection{Sifat Fisik Tanah}

Sifat fisik tanah dalam penelitian ini meliputi: kerapatan lindak (bulk density), porositas, permeabilitas dan tekstur tanah. Hasil analisis dari sampel tanah utuh dan terusik dari areal bekas terbakar (19 tahun) dan areal tidak terbakar di kawasan Prevab, Taman Nasional Kutai disajikan pada Tabel 2 di bawah ini. 
Tabel 2. Sifat Fisik Tanah Di Lokasi Penelitian

\begin{tabular}{cccccccc}
\hline Areal & $\begin{array}{c}\text { Kedalaman } \\
\text { Tanah } \\
(\mathrm{cm})\end{array}$ & $\begin{array}{c}\text { BD } \\
\left(\mathrm{g} / \mathrm{cm}^{3}\right)\end{array}$ & $\begin{array}{c}\text { Poro- } \\
\text { sitas } \\
(\% \mathrm{~V})\end{array}$ & $\begin{array}{c}\text { Permea- } \\
\text { bilitas } \\
(\mathrm{cm} / \mathrm{jam})\end{array}$ & $\begin{array}{c}\text { Tekstur Tanah } \\
(\%)\end{array}$ & $\begin{array}{c}\text { Pasir } \\
\text { Debu }\end{array}$ & Liat \\
\hline BT 1 & $0-30$ & 1,46 & 35,85 & 1,51 & 66,03 & 23,86 & 10,70 \\
BT 2 & $0-30$ & 1,75 & 34,14 & 0,86 & 63,03 & 26,10 & 10,87 \\
Rataan & $0-30$ & 1,60 & 34,99 & 1,19 & 64,53 & 24,68 & 10,78 \\
TT 1 & $0-30$ & 1,23 & 37,04 & 0,42 & 49,38 & 36,02 & 14,60 \\
TT 2 & $0-30$ & 1,33 & 36,33 & 2,73 & 53,72 & 28,14 & 18,17 \\
Rataan & $0-30$ & 1,28 & 36,68 & 1,58 & 51,55 & 32,08 & 16,38 \\
\hline Keterangan: BT = Bekas Terbakar; TT = Tidak Terbakar & & & &
\end{tabular}

\subsubsection{Kerapatan lindak (bulk density/BD)}

Kerapatan Lindak merupakan cara untuk menyatakan bobot tanah, dalam hal ini jumlah ruangan dalam tanah (ruang yang ditempati padatan, air dan gas) turut diperhitungkan (Prakoso, 2004). Semakin tinggi bobot isi, maka tanah tersebut akan semakin padat. Bobot isi tanah dapat bervariasi dari waktu ke waktu atau dari lapisan ke lapisan sesuai dengan perubahan ruang pori atau struktur tanah. Tanah yang mempunyai bobot isi besar akan sulit meneruskan air atau sukar ditembus oleh akar tanaman, sebaliknya tanah dengan bobot isi rendah, akar tanaman akan lebih mudah berkembang (Hardjowigeno, 1989). BD dipengaruhi oleh tekstur tanah, struktur tanah, dan kandungan bahan organik. Selain itu, BD dapat cepat berubah karena pengolahan tanah dan praktek budidaya (Hardjowigeno, 2007).

Berdasarkan Tabel 2 diketahui bahwa nilai BD pada areal bekas terbakar lebih tinggi yaitu rata-rata sebesar $1,60 \mathrm{~g} / \mathrm{cm} 3$ dibandingkan dengan areal yang tidak terbakar yang memiliki BD rata-rata $1,28 \mathrm{~g} / \mathrm{cm}^{3}$. Pemanasan akibat kebakaran dapat meningkatkan suhu permukaan tanah yang tinggi yang akan menyebabkan kerusakan struktur permukaan tanah dan berkurangnya ruang pori tanah yang secara nyata akan meningkatkan BD (Prakoso, 2004). Hidayat (2006) mengemukakan bahwa kenaikan BD disebabkan oleh proses pengembangan koloid-koloid tanah akibat pengaruh panas dari pembakaran sehingga tanah menjadi lebih padat, serta adanya proses pengabuan dari bahan bakar terkonsumsi yang menutupi permukaan tanah turut berperan pula dalam pemadatan tanah, dengan cara abu yang terbentuk masuk pada pori-pori tanah sehingga BD tanah meningkat.

\subsubsection{Porositas}

Dari Tabel 2 diketahui bahwa pada areal bekas terbakar memiliki nilai porositas rata-rata $34,99 \%$, sedangkan pada areal tidak terbakar memiliki nilai rata-rata $36,68 \%$. Hal tersebut menunjukkan bahwa tanah pada areal bekas terbakar mempunyai porositas yang lebih rendah dibandingkan dengan areal tidak terbakar. 
Lebih rendahnya nilai porositas tanah pada areal bekas terbakar terjadi karena dipengaruhi oleh peningkatan kepadatan tanah (peningkatan nilai BD) akibat terbakarnya serasah dan bahan organik yang menimbulkan pengembangan koloid-koloid tanah yang mempersempit dan mengurangi jumlah ruang pori dalam tanah. Selain itu, abu sisa pembakaran yang masuk ke dalam pori tanah terutama pori makro menyebabkan jumlah ruang pori tanah berkurang. Hardjowigeno (1995) mengemukakan bahwa dengan adanya porositas yang tinggi, maka bahan organik dapat memperkecil kerapatan isi tanah karena bahan organik jauh lebih ringan daripada mineral dan bahan organik juga memperbesar porositas tanah.

\subsubsection{Permeabilitas}

Permeabilitas tanah adalah kemampuan tanah untuk meneruskan air atau udara. Permeabilitas tanah biasanya diukur dengan istilah kecepatan air yang mengalir dalam waktu tertentu yang ditetapkan dalam satuan cm/jam (Hakim et al., 1986). Permeabilitas tanah dipengaruhi antara lain oleh tekstur, porositas tanah serta distribusi ukuran pori, stabilitas agregat, struktur tanah, dan kandungan bahan organik (Prakoso, 2004).

Dari Tabel 2 diketahui bahwa pada areal bekas terbakar memiliki nilai rerata permeabilitas $1,58 \mathrm{~cm} / \mathrm{jam}$ (agak lambat), sedangkan pada areal tidak terbakar nilai rerata permeabilitasnya sebesar $1,19 \mathrm{~cm} / \mathrm{jam}$ (agak lambat).

Dari uraian di atas, terdapat hubungan kecenderungan antara BD, porositas dan permeabilitas, yaitu bahwa jika BD-nya tinggi (tanah semakin padat) akan menurunkan porositas dan permeabilitas tanah. Pemadatan tanah mengakibatkan tanah menjadi tidak permeable sehingga aerasi dan drainase dalam tanah menjadi terhambat.

\subsubsection{Tekstur tanah}

Tekstur tanah merupakan perbandingan proporsi fraksi tanah, yaitu pasir, debu dan liat. Fraksi-fraksi tersebut memiliki sifat fisik, kimia dan biologis yang berbeda-beda. Selain itu juga ada faktor yang mempengaruhi tekstur tanah seperti air, waktu, bahan induk, organisme, dan topografi (Hardjowigeno 1995).

Tanah yang bertekstur pasir mempunyai luas permukaan yang kecil sehingga sulit menyerap (menahan) air dan unsur hara. Tanah-tanah bertekstur liat mempunyai luas permukaan yang besar sehingga kemampuan menahan air dan menyediakan unsur hara tinggi (Hardjowigeno, 2007).

Berdasarkan pada Tabel 2 di atas dapat diketahui bahwa tekstur tanah areal bekas terbakar tergolong bertekstur kasar yaitu lempung berpasir (Sandy Loam/SL), yang ditunjukkan oleh dominasi fraksi pasir dengan nilai rata-rata $64.53 \%$, diikuti debu dengan nilai rerata $24,68 \%$, dan sebaran fraksi liat sebesar $10,78 \%$, sedangkan pada areal tidak terbakar tergolong bertekstur sedang yaitu lempung (Loam/L) dengan fraksi yang 
dominan adalah pasir dengan nilai rerata $51,55 \%$, diikuti debu dengan nilai rerata $32,08 \%$, dan sebaran fraksi liat sebesar 16,38\%.

Selain merusak terhadap tegakan, kebakaran juga dapat mengubah sifat fisik dan kimia tanah. Dengan terbukanya tajuk, mengakibatkan lantai hutan tidak memiliki pelindung yang akan memberi peluang terhadap aliran air permukaan jika hujan turun dan akan mengakibatkan erosi permukaan yang tidak terkendali. Erosi permukaan akan membawa serta lapisan tanah atas dimulai dari partikel yang terkecil dan akan ke yang lebih besar apabila terdapat daya angkut yang lebih besar. Lebih jauh dampak yang dialami ialah porositas dan kecepatan infiltrasi tanah menurun serta bulk density tanah meningkat disebabkan agregat tanah terdispersi oleh pukulan butir-butir air hujan dan tertutupnya pori-pori tanah oleh partikel abu pembakaran sehingga menurunkan basarnya ruang pori tanah, infiltrasi dan aerasi tanah (Pritchett, 1979).

\subsection{Sifat Kimia Tanah}

Hasil uji laboratorium terhadap beberapa sifat kimia sampel tanah dari lokasi penelitian, diperoleh hasil sebagai berikut:

Tabel 3. Kriteria Penilaian Hasil Analisis Sifat Kimia Tanah di Areal Penelitian

\begin{tabular}{lll}
\hline Sifat Kimia Tanah & Areal Bekas Terbakar & Areal Tidak Terbakar \\
\hline $\mathrm{pH}$ & 3,71 (Sangat Masam) & 3,70 (Sangat Masam) \\
$\mathrm{DHL}(\mathrm{mS} / \mathrm{cm})$ & 0,10 (Sangat Rendah) & 0,17 (Sangat Rendah) \\
$\mathrm{KTK}(\mathrm{me} / 100 \mathrm{gr})$ & 8,50 (Rendah) & 9,10 (Rendah) \\
\hline
\end{tabular}

\subsection{1 pH tanah}

Berdasarkan hasil analisis laboratorium pada Tabel 3 diketahui bahwa nilai $\mathrm{pH}$ tanah pada areal bekas terbakar 3,71 (sangat masam). Nilai tersebut hampir sama dengan $\mathrm{pH}$ pada areal tidak terbakar yaitu 3,70 (sangat masam). Berdasarkan hasil tersebut menunjukkan bahwa nilai $\mathrm{pH}$ tidak jauh berubah setelah 19 tahun terjadi kebakaran yaitu tergolong sangat masam. Hal ini diduga dipengaruhi curah hujan yang tinggi, mengingat lokasi penelitian memiliki curah hujan yang tinggi (188 mm/bulan), berdasarkan klasifikasi iklim Schmidt dan Ferguson termasuk tipe iklim A. kondisi demikian menyebabkan tingginya tingkat pencucian oleh curah hujan.

Penelitian Yudasworo (2001) menunjukkan bahwa nilai pH mengalami peningkatan pada saat terbakar, dan setelah 8 bulan kebakaran yaitu dari 4,40 menjadi 4,60 pada saat terbakar dan menjadi 4,80 setelah 8 bulan kebakaran. Demikian juga Widyasari (2008) menyatakan bahwa nilai rerata $\mathrm{pH}$ mengalami peningkatan sebesar 0,37 yaitu 3,08 pada tanah tidak terbakar menjadi 3,45 pada tanah bekas terbakar 2 tahun. Ini menunjukkan bahwa dengan kejadian kebakaran hutan, $\mathrm{pH}$ tanah menjadi meningkat sehingga unsur hara tertentu yang dibutuhkan bagi tanaman menjadi tersedia. 
Namun demikian hal tersebut tidak selalu berlangsung tetap, $\mathrm{pH}$ akan turun kembali mendekati pH awal setelah 5 tahun (Iswanto, 2005). Sejalan dengan itu, Saharjo (1995) mengemukakan bahwa kebakaran tidak mungkin dapat memperbaiki kesuburan tanah dalam jangka panjang karena efeknya hanya bersifat sementara.

Selain itu hal yang menyebabkan bahwa setelah kebakaran hutan tidak meningkatkan nilai $\mathrm{pH}$ tanah dalam kurun waktu tertentu adalah sifat dasar dari tanah tersebut yaitu podsolik dengan $\mathrm{pH}$ sangat masam-masam. Iklim tropis yang panas dengan curah hujan tinggi mengakibatkan unsur hara penting mudah tercuci dengan sangat cepat sehingga tanah kembali menjadi masam. Besar dan kecepatan perubahan $\mathrm{pH}$ tanah ini berbeda-beda yang tergantung dari sifat tanah dan banyaknya abu (Sanchez, 1992).

\subsubsection{Daya hantar listrik (DHL)}

Nilai Daya hantar listrik (DHL) mencerminkan kadar garam yang terlarut. Peningkatan konsentrasi garam yang terlarut akan menigkatkan nilai DHL larutan (Anonim, 2012). Daya hantar listrik (DHL) akan berpengaruh terhadap kandungan garam yang ada di dalam tanah. Semakin tinggi nilai DHL maka kandungan garam di dalam tanah akan tinggi. Garam mempengaruhi pertumbuhan tanaman umumnya melalui keracunan yang diakibatkan penyerapan unsur penyusun garam secara berlebihan, dan penurunan penyerapan air yang dikenal sebagai cekaman air, atau penurunan dalam penyerapan unsur hara yang penting bagi tanaman (FAO, 2005).

Berdasarkan hasil analisis pada Tabel 4 menunjukan bahwa pada areal bekas terbakar memiliki nilai $\mathrm{DHL}$ sebesar $0,10 \mathrm{mS} / \mathrm{cm}$ (sangat rendah), dan pada areal tidak terbakar sebesar $0,17 \mathrm{mS} / \mathrm{cm}$ (sangat rendah). Pada areal bekas terbakar memiliki nilai DHL yang lebih rendah dibandingkan dengan lokasi yang tidak terbakar. Hal tersebut diduga dipengaruhi oleh konsentrasi $\mathrm{Na}^{+}$yang lebih rendah pada areal bekas terbakar dibandingkan dengan areal tidak terbakar.

\subsubsection{Kapasitas tukar kation (KTK)}

Kapasitas Tukar Kation (KTK) menunjukkan kemampuan tanah untuk menahan kation-kation dan mempertukarkan kation-kation tersebut. Tanah dengan KTK tinggi mampu menyerap dan menyediakan unsur hara lebih baik daripada tanah dengan KTK rendah (Hardjowigeno, 2007). Beberapa hal yang dapat mempengaruhi KTK yaitu: reaksi tanah $(\mathrm{pH})$, tekstur tanah, kandungan bahan organik dan tindakan pengelolaan, misalnya pemupukan.

Dalam Tabel 3 diketahui bahwa Kapasitas Tukar Kation (KTK) tanah di lokasi penelitian tergolong ke dalam kriteria/status rendah dengan nilai KTK di areal bekas terbakar sebesar 8,5 me/100 gr (rendah) dan di areal tidak terbakar sebesar 9,1 me/100 gr (rendah). Lebih rendahnya nilai KTK di areal bekas terbakar dibandingkan dengan 
areal tidak terbakar diduga berkaitan dengan kandungan C-organik. Tanah-tanah yang memiliki KTK tinggi dipengaruhi oleh keberadaan C-organik yang tinggi dari hasil dekomposisinya yang menghasilkan kation-kation basa sehingga KTK meningkat. Semakin tinggi kandungan bahan organik tanah, maka kapasitas KTK tanah akan semakin tinggi.

Kandungan bahan organik berkorelasi positif terhadap (KTK) karena lambat laun hara akan tersedia dari dekomposisi bahan organik dan juga tanah akan lebih kuat menahan unsur hara karena strukturnya yang membentuk agregat yang lebih stabil. Jika kandungan humus dan bahan organik di dalam tanah sedikit akan menyebabkan penurunan KTK karena hilangnya unsur hara akibat pencucian maupun erosi.

\subsubsection{Kation basa ( $\mathrm{Ca}, \mathrm{Mg}, \mathrm{K}, \mathrm{Na})$}

Hasil analisis tanah terhadap kation-kation basa $(\mathrm{Ca}, \mathrm{Mg}, \mathrm{K}, \mathrm{Na})$ pada lokasi penelitian dan kriterianya disajikan dalam Tabel 4 berikut ini:

Tabel 4. Analisis Kation Basa Tanah di Lokasi Penelitian (me/100 gr)

\begin{tabular}{ccc}
\hline Kation Basa & Lokasi Bekas Terbakar & Lokasi Tidak Terbakar \\
\hline $\mathrm{Ca}^{++}$ & 1,96 (Sangat Rendah) & 5,07 (Rendah) \\
$\mathrm{Mg}^{++}$ & 0,65 (Rendah) & 1,67 (Sedang) \\
$\mathrm{K}^{+}$ & 0,19 (Rendah) & 0,14 (Rendah) \\
$\mathrm{Na}^{+}$ & 0,31 (Rendah) & 0,43 (Sedang) \\
\hline
\end{tabular}

Berdasarkan Tabel 4 dapat dikemukakan bahwa secara umum tanah di areal bekas terbakar memiliki jumlah kation basa yang lebih rendah jika dibandingkan dengan areal tidak terbakar. Lebih rendahnya kation yang dipertukarkan pada areal bekas terbakar juga menunjukkan tingkat kesuburan yang lebih rendah jika dibandingkan dengan areal tidak terbakar.

Pada tabel tersebut diketahui juga bahwa pada areal bekas terbakar memiliki Kalsium (Ca) dengan kriteria sangat rendah, sedangkan Magnesium (Mg), Kalium (K) dan Natrium ( $\mathrm{Na}$ ) termasuk dalam kriteria rendah. Pada areal tidak terbakar menunjukkan bahwa $\mathrm{Ca}$ dan $\mathrm{K}$ termasuk kriteria rendah, sedangkan $\mathrm{Mg}$ dan $\mathrm{Na}$ termasuk dalam kriteria sedang.

Jika dibandingkan kedua areal tersebut diketahui bahwa pemulihan alami setelah 19 tahun mengalami kebakaran jumlah kation $\mathrm{Ca}, \mathrm{Mg}$ dan $\mathrm{Na}$ masih lebih rendah dibandingkan lokasi tidak terbakar, kecuali untuk $\mathrm{K}$ status kesuburannya sama antara areal bekas terbakar dan tidak terbakar yaitu rendah. Nilai K pada areal terbakar lebih tinggi dibandingkan areal tidak terbakar.

Hasil analisis $\mathrm{K}$ memperlihatkan bahwa perubahan nilai $\mathrm{K}$ meningkat setelah kebakaran. Hal ini diduga setelah pembakaran, kation basa $K$ di dalam abu akan 
menyebabkan peningkatan basa K dapat ditukar yang luar biasa besar (Sanchez, 1992). Penelitian Widyasari (2008) menunjukkan jumlah K pada areal tidak terbakar mengalami peningkatan pada areal yang terbakar. Peningkatan jumlah $\mathrm{K}$ setelah pembakaran diduga selain disebabkan adanya suplai $\mathrm{K}$ dari abu sisa hasil pembakaran yang meresap ke dalam tanah, juga dapat berasal dari jaringan-jaringan yang ada di permukaan tanah (Hakim et al., 1986). Selain itu, lebih tingginya K pada areal bekas terbakar diduga dipengaruhi juga oleh tingkat penyerapan vegetasi terhadap unsur $\mathrm{K}$.

\section{Kesimpulan}

Berdasarkan penelitian ini dapat disimpulkan bahwa; (1) sampai 19 tahun setelah terbakar, diketahui kebakaran hutan berdampak terhadap sifat fisik tanah, yaitu meningkatnya kerapatan lindak/bulk density, penurunan porositas dan permeabilitas tanah serta tekstur tanah dengan fraksi pasir lebih dominan; (2) Sifat kimia tanah memiliki kriteria yang sama antara areal bekas terbakar dan tidak terbakar yaitu $\mathrm{pH}$ sangat masam, DHL sangat rendah dan KTK rendah, sedangkan (3) kation-kation basa secara umum lebih tinggi pada areal tidak terbakar dibandingkan dengan areal terbakar, kecuali untuk Kalium (K).

\section{Daftar Pustaka}

Anonim. 2012. Petunjuk Teknis Analsis Kimia Tanah, Tanaman, Air dan Pupuk. Badan Penelitian dan Pengembangan Pertanian, Kementerian Pertanian.

Chandler, C., P. Cheney, L. Trabaud dan D. William. 1983. Fire in Forest Fire Behaviour and Effect. 1: 171-180 Canada. USA.

FAO. 2005. 2 Hal Untuk Diketahui tentang Dampak Air Laut pada Lahan Pertanian di Provinsi NAD. Buku Panduan Lapang. NAD.

Hakim, N., N. Yusuf, A. M. Lubis, G. N. Sutopo, M. Amin, H. H. Bailley dan B. H. Go. 1986. Dasar-dasar Ilmu Tanah. Universitas Lampung. Lampung.

Hardjowigeno, S. 1989. Sifat-Sifat dan Potensi Gambut Sumatera untuk Pengembangan Pertanian. Prosiding Seminar Gambut untuk Pertania, Fakultas Pertanian USU, Medan.

Hardjowigeno, S. 1995. IImu Tanah. Akademikan Pressindo. Jakarta.

Hardjowigeno, S. 2007. Ilmu Tanah. Akademikan Pressindo. Jakarta.

Hatta, M. 2009. Dampak Kebakaran Hutan terhadap Sifatsifat Tanah di Kecamatan Besitang Kabupaten Langkat. Skripsi Universitas Sumatera Utara. Medan.

Hidayat, E.J.E. 2006. Dampak Kebakaran Di Padang Rumput Terhadap Sifat Fisik dan Kimia Tanah. Departemen Manajemen Hutan Fakultas Kehutanan Institut Pertanian Bogor.

Iswanto, D. S. 2005. Perubahan Sifat Fisik dan Kimia Gambut pada Lahan Bekas Terbakar di Tegakan Acacia crassicarpa PT. Sebangun Bumi Andalas Wood Industries, Propinsi Sumatera Selatan. Skripsi. Institut Pertanian Bogor. Bogor. 
Prakoso, Y. 2004. Dampak Kebakaran Hutan terhadap Sifat Fisika Tanah di Hutan Tanaman Sekunder Akasia (Acacia mangium) di Desa Langensari Kecamatan Parung Kuda Sukabumi, Jawa Barat. Skripsi. Institut Pertanian Bogor. Bogor.

Pritchett, W.L. 1979. Properties and Management of Forest Soil. John Willey and Sons. New York

Ramadhan, I.M. 2011. Desain Paket Kunjungan Wisata Sebagai Alternatif Pengembangan Ekowisata di Taman Nasional Kutai Dusun Kabo Jaya Kabupaten Kutai Timur. Skripsi Program Studi Kehutanan STIPER Kutai Timur, Sangatta.

Sagala, P.S., D. Elfiati, dan Delvian. 2006. Dampak Kebakaran HutanTerhadap Sifat Fisika dan Sifat Kimia Tanah di Kabupaten Samosir. Program Studi Kehutanan Fakultas Pertanian Universitas Sumatera Utara. Medan

Saharjo, B. H. 1995. Acacia mangium Amankah dari Gangguan. Rimba Indonesia $X X X(3): 40-50$. Jakarta.

Sanchez, P. A. 1992. Sifat dan Pengelolaan Tanah Tropika. Institut Teknologi Bandung. Bandung.

Wasis, B. 2003. Dampak Kebakaran Hutan Dan Lahan Terhadap Kerusakan Tanah. Jurnal Manajemen Hutan Tropika IX (2): 79-86.

Widyasari, N. dan A. Eka. 2008. Pengaruh Sifat Fisik dan Kimia Tanah Gambut Dua Tahun setelah Terbakar dalam Mempengaruhi Pertumbuhan Acacia crassicarpa a. Cunn. Ex Benth Di Areal IUPHHKHT PT. Sebangun Bumi Andalas Wood Industries. Skripsi. Institut Pertanian Bogor. Bogor.

WWF. 2015. 4 Dampak yang Sangat Merugikan dari Kebakaran Hutan http://earthhour.wwf.or.id/4.

Yudasworo, D.I. 2001. Dampak Kebakaran Hutan terhadap Sifat Fisik dan Kimia Tanah (Studi Kasus di Hutan Sekunder Haurbentes Jasinga-Bogor. Skripsi. Institut Pertanian Bogor. Bogor. 